\title{
Cadmium Chemical Forms in Two Calcareous Soils Treated with Different Levels of Incubation Time and Moisture Regimes
}

\author{
Farzad Rassaei ${ }^{1}$, Mehran Hoodaji ${ }^{*}$, Seyed Ali Abtahi ${ }^{2}$ \\ ${ }^{1}$ Department of Soil Science, Isfahan (Khorasgan) Branch, Islamic Azad University, Isfahan, Iran \\ ${ }^{2}$ Department of Soil Science, Shiraz University, Shiraz, Iran \\ Email: *M_hoodaji@khuisf.ac.ir
}

How to cite this paper: Rassaei, F., Hoodaji, M. and Abtahi, S.A. (2019) Cadmium Chemical Forms in Two Calcareous Soils Treated with Different Levels of Incubation Time and Moisture Regimes. Journal of Environmental Protection, 10, 500-513. https://doi.org/10.4236/jep.2019.104029

Received: March 18, 2019

Accepted: April 7, 2019

Published: April 10, 2019

Copyright $\odot 2019$ by author(s) and Scientific Research Publishing Inc. This work is licensed under the Creative Commons Attribution International License (CC BY 4.0).

http://creativecommons.org/licenses/by/4.0/

\begin{abstract}
Sequential extraction is used effectively to determine the chemical forms of heavy metals. Since few studies have been conducted in calcareous soils of Iran, the current research has been carried out to evaluate the effect of moisture regimes and incubation time on the chemical forms of cadmium in two calcareous soils. Treatments included three levels of cadmium $(0,30$ and $60 \mathrm{mg} / \mathrm{kg}$ of soil as $\mathrm{CdSo}_{4}$ ), three incubation times (2, 4 and 8 weeks), two soils (clay and sandy clay loam) and two moisture regimes (Waterlogged and Field capacity). The experiment was performed as factorial on the basis of randomized complete blocks design with two replications. At 2, 4 , and 8 weeks after treatment, the Tessier et al. (1979) sequential extraction method was applied to measure the cadmium concentration in water soluble-exchangeable (WsEx.), iron and manganese oxide (Fe-MnOx.), carbonate (Car.), organic matter (Om.) and residual forms (Res.). The results showed depending on the soil texture, 68 to 72 percent of the cadmium was in water soluble-exchangeable and iron-manganese oxide forms. Flooding condition decreased the concentration of cadmium in water soluble + exchangeable form and increased the concentration of cadmium in the forms of $\mathrm{Fe}-\mathrm{Mn}$ oxides, carbonate and organic matter. Concentration of cadmium in residual form was higher in clay soil. In sandy clay loam soil, water soluble-exchangeable, carbonate and organic matter forms were higher than clay soil. The iron-manganese oxides form showed no significant difference in two soils at field capacity regime. In flooding conditions, the concentration of the water soluble-exchangeable form decreased and the concentration of other forms increased. In contrast to the oxidizing conditions at the reduction conditions, no significant difference was observed in the residual and organic matter forms in two soils.
\end{abstract}




\section{Keywords}

Cadmium, Chemical Forms, Flooding, Sequential Extraction, Waterlogged

\section{Introduction}

Cadmium is a non-essential element which is absorbed by plants [1]. Changing in moisture regimes in soil has a large effect on soil redox potential and as a result on metal solubility [2]. At highly reducing condition in soil, Cd solubility decreases due to formation of Cd-sulphide complexes [3] [4]. Insoluble $\mathrm{Fe}^{3+}$ and $\mathrm{Mn}^{4+}$ hydrous oxides in aerobic soils provide sorption surface for $\mathrm{Cd}$ and other metals' ions [5] [6] [7] [8]. At flooding condition and decreasing redox potential, $\mathrm{Mn}^{4+}$ and $\mathrm{Fe}^{3+}$ become reduced to more soluble oxidation states $\mathrm{Mn}^{2+}$ and $\mathrm{Fe}^{2+}$ [6] [7] [8]. Dissolution of $\mathrm{Mn}$ and Fe hydrous oxides releases the co-sorbed metal ions into soil solution and increasing metal absorption by plants. Zn dynamic in soil is based on organic matter, $\mathrm{pH}$ and soil clay contents. $\mathrm{Fe}, \mathrm{Mn}$ and $\mathrm{Al}$ oxides, clays and organic matter prepare sorption surfaces for adsorbing $\mathrm{Zn}$ [9]. By increasing $\mathrm{Mn}^{2+}$ and $\mathrm{Fe}^{2+}$ in aerobic condition, $\mathrm{Zn}$ can be precipitate in forms with less solubility [10]. As the $\mathrm{Mn}^{2+}$ and $\mathrm{Fe}^{2+}$ forms are more soluble than the oxidized forms, they compete with $\mathrm{Zn}$ for sorption sites on the organic matter [17]. Cadmium and Zinc have similar chemical characteristics; they both are absorbed by plants and are retained in soil exchangeable sites as a divalent cation [18]. Adjusting $\mathrm{pH}$ by land flooding has positive effects on $\mathrm{Zn}$ availability [19]. Submerging alkaline soil causes decreasing in soil $\mathrm{pH}$; organic matter acts as an electron donor while ferric ion acts as an electron receptor [20]. This process increases carbon dioxide and decreases soil $\mathrm{pH}$ [21]. Because of the limited diffusion in the standing water on the soil surface, $\mathrm{CO}_{2}$ is remained in the soil causes mild acidity which neutralizes soil $\mathrm{pH}$ and solubilises $\mathrm{Zn}$ [22]. Depleting oxygen during the flooding periods decreases Eh [23] [24]. The objectives of this research were to examine the effect of incubation time and moisture regime on cadmium chemical forms in two calcareous soils.

\section{Materials and Methods}

\subsection{Soil}

In order to execute this research, two types of soils (top soil, a depth of 0 to 25 $\mathrm{cm}$ ) were collected from Sarvestan series and Kamfiroz series of Fars province, Iran. Soils in the Classification [11], are Calcic Haploxeralfs and different in terms of texture, Cation exchange capacity (CEC), and calcium carbonate equivalent (CCE). Soil samples were air dried and passed from a $2 \mathrm{~mm}$ sieve. Soils texture by the hydrometer method [12], electrical conductivity (EC) in the 1:1 soil - water suspension [13], carbonate calcium equivalent (CCE) by the hydrochloric acid neutralizing method [14], $\mathrm{pH}$ by the 1:1 suspension of soil - water [14], organic carbon by the method of Walkaly and Black [15] and available 
Fe, $\mathrm{Mn}, \mathrm{Cu}, \mathrm{Zn}$ and $\mathrm{Cd}$ extracting with the $0.005 \mathrm{M} \mathrm{DTPA}[16]$ were determined (Table 1).

\subsection{Test of Incubation Time on Cadmium Chemical Forms at Field Capacity Regime}

The experiment was accomplished as factorial on the basis of randomized complete blocks design with tow replications. The factors were three levels of $\mathrm{Cd}(0$, 30 and $60 \mathrm{mg} / \mathrm{kg}$ of soil) and three levels of incubation times (2, 4 and 8 weeks). The incubation experiment was carried out in plastic beaker. Each pot $(0.5 \mathrm{~kg}$ soil) was treated with three levels of $\mathrm{Cd}$ from cadmium sulfate source (Merck Co. Germany) and were placed in Field Capacity (33 kPa) situation. The pots were covered by porous plastic sheets. To prevent the fast evaporation of soil samples, the pots were placed in an incubator at $25^{\circ} \mathrm{C}$ temperature. The moisture content of the samples was checked every two days and the soils were mixed well every 5 days.

\subsection{Test of Incubation Time on Cadmium Chemical Forms at Waterlogged Regime}

The experiment was accomplished as factorial on the basis of randomized complete blocks design with tow replications. The factors were three levels of $\mathrm{Cd}(0$, 30 and $60 \mathrm{mg} / \mathrm{kg}$ of soil) and three levels of incubation times (2, 4 and 8 weeks). The incubation experiment was carried out in plastic beaker. Each pot $(0.5 \mathrm{~kg}$ soil) was treated with three levels of $\mathrm{Cd}$ from cadmium sulfate source (Merck Co. Germany) and was placed in flooding situation (waterlogged). For flooding

Table 1. Selected chemical properties of soils used.

\begin{tabular}{|c|c|c|}
\hline \multirow[t]{2}{*}{ Properties } & \multicolumn{2}{|c|}{ Amount } \\
\hline & Kamfiroz series & Sarvestan series \\
\hline Sand (\%) & 51.8 & 12 \\
\hline Silt (\%) & 25.5 & 34.8 \\
\hline Clay (\%) & 22.7 & 53.2 \\
\hline Texture & Sandy Clay Loam & Clay \\
\hline OM (\%) & 3.4 & 2.61 \\
\hline CCE (\%) & 52.3 & 34.1 \\
\hline $\mathrm{CEC}\left(\mathrm{Cmol} \cdot \mathrm{kg}^{-1}\right)$ & 8.34 & 30.31 \\
\hline $\mathrm{EC}\left(\mathrm{dS} \cdot \mathrm{m}^{-1}\right)$ & 0.74 & 0.76 \\
\hline $\mathrm{pH}(1: 1)$ & 7.92 & 7.38 \\
\hline $\mathrm{Fe}(\mathrm{mg} / \mathrm{kg})$ & 3.3 & 4.4 \\
\hline $\mathrm{Mn}(\mathrm{mg} / \mathrm{kg})$ & 5.4 & 8.7 \\
\hline $\mathrm{Zn}(\mathrm{mg} / \mathrm{kg})$ & 0.33 & 0.51 \\
\hline $\mathrm{Cu}(\mathrm{mg} / \mathrm{kg})$ & 0.93 & 1.42 \\
\hline $\mathrm{Cd}(\mathrm{mg} / \mathrm{kg})$ & nd & nd \\
\hline
\end{tabular}


(FD) regime, deionized water was added to the soil samples to create a $5 \mathrm{~cm}$ layer of water above the soils. The pots were covered by porous plastic sheets. To prevent the fast evaporation of soil samples, the pots were placed in an incubator at $25^{\circ} \mathrm{C}$ temperature. The moisture content of the samples was checked every two days and the soils were mixed well every 5 days.

\section{Sequential Extraction Procedure}

Soils were sampled at 2, 4 and 8 weeks after the beginning of treatments, The sequential extraction proposed by Tessier [25] was used in this study, The chemical fractions of heavy metals are defined in (Table 2). Extractions were put in $100 \mathrm{ml}$ centrifuge tubes. Between each consecutive extraction, the supernatant was centrifuged for $30 \mathrm{~min}$ at $4000 \mathrm{r} / \mathrm{min}$ and then purified. The total cadmium concentration in soils were determined by digesting $0.5 \mathrm{~g}$ soil samples (oven dry weight) with HNO3_HF_HClO4 mixture accompanied by elemental analysis, the concentrations of $\mathrm{Cd}$ in all solutions were studied by an atomic absorption spectrophotometer (AA 670).

\section{Statistical Analysis}

Statistical analysis was performed with SPSS Version 16.0 statistic software package. Data were demonstrated as means \pm standard deviation (SD). Differentiations between groups were performed with analysis of non-parametric test. A value of $\mathrm{P}<0.05$ was regarded statistically significant. The Duncan's multiple range tests used to decide statistical significance of the effects due to treatments and their interaction.

\section{Results and Discussion}

\subsection{Effect of Time on Chemical Forms of Cadmium at Field Capacity Regime}

The results showed significant effect of incubation time on the cadmium forms in soil. Through time, some forms followed a steady trend upward or downward (Figure 1 and Figure 2). In both textures and at all levels of cadmium, the water

Table 2. Summary of the sequential extraction method provided by Tessier and et al. (1979) to determine the chemical forms of cadmium.

\begin{tabular}{|c|c|c|c|c|c|}
\hline Row & Chemical forms & Time (h) & Temperature $\left({ }^{\circ} \mathrm{C}\right)$ & $\begin{array}{l}\text { Soil (g)/Solution } \\
\text { Volume (ml) }\end{array}$ & Used solution \\
\hline 1 & $\begin{array}{l}\text { Water Soluble and } \\
\text { Exchangeable WsEx. }\end{array}$ & 1 & 25 & 16 & $\mathrm{MgCl}_{2}(1 \mathrm{~mol} / \mathrm{l}), \mathrm{pH}=7$ \\
\hline 2 & Carbonate Car. & 5 & 25 & 16 & $\mathrm{NaOAc}(1 \mathrm{~mol} / \mathrm{l}), \mathrm{pH}=5$ \\
\hline 3 & $\begin{array}{l}\text { Iron and Manganese } \\
\text { Oxides Fe-MnOx. }\end{array}$ & 6 & 96 & 16 & $\mathrm{NH}_{2} \mathrm{OH} \cdot \mathrm{HCl}(0.04 \mathrm{~mol} / \mathrm{l})$ in $\mathrm{HOAc}(\% 25 \mathrm{v}: \mathrm{v}), \mathrm{pH}=2$ \\
\hline 4 & Organic Om. & 5.5 & 85 & 16 & $\begin{array}{c}3 \mathrm{ml} \mathrm{HNO}_{3}(0.02 \mathrm{~mol} / \mathrm{l}), 8 \mathrm{ml} \mathrm{H} \mathrm{O}_{2}(\% 30), \mathrm{pH}=2 \\
5 \mathrm{ml} \mathrm{NH} \mathrm{HAc}_{4} \mathrm{OA}(3.2 \mathrm{~mol} / \mathrm{l}) / \mathrm{HNO}_{3}(\% 20 \mathrm{v} \text { in v) }\end{array}$ \\
\hline 5 & Residual Res. & 2 & 130 & 16 & $(3: 1 \mathrm{v} / \mathrm{v}) \mathrm{HCl}: \mathrm{HNO}_{3}$ \\
\hline
\end{tabular}




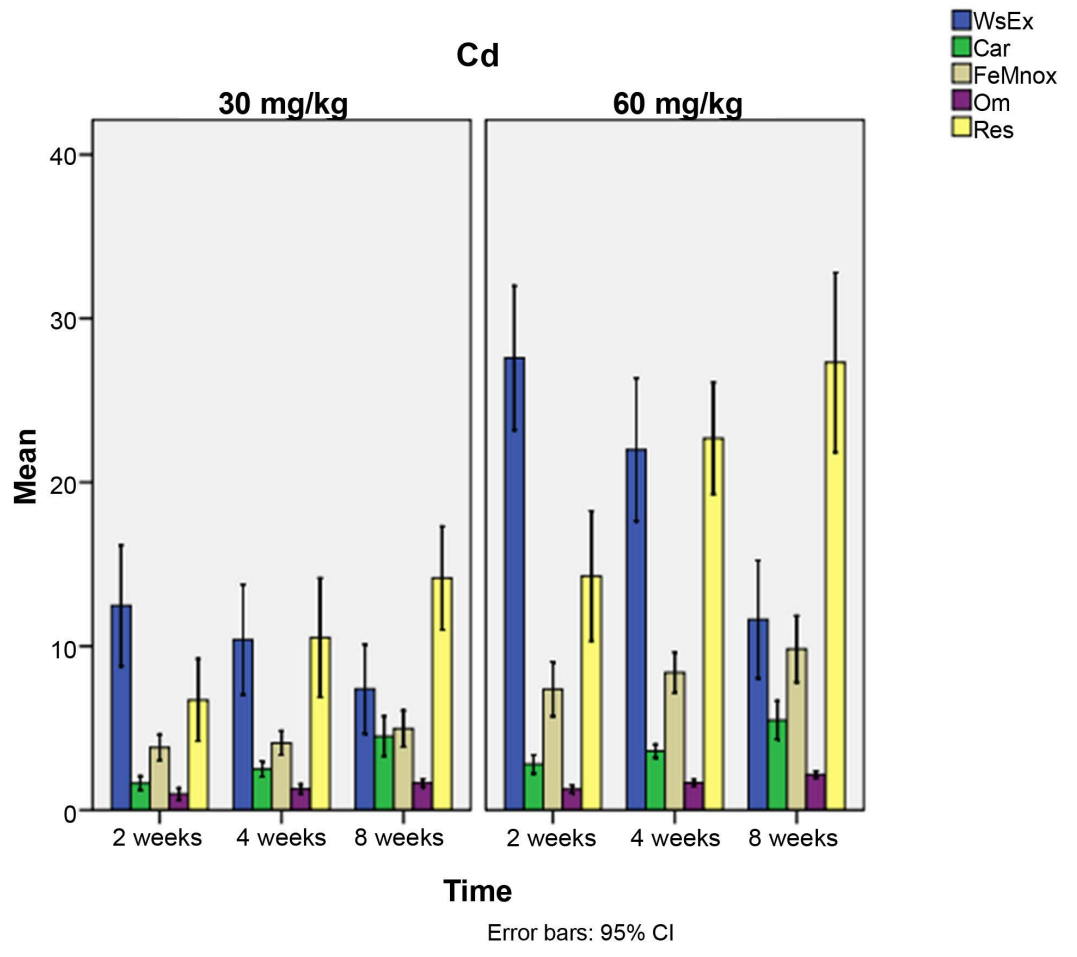

Figure 1. Effect of 30 and $60 \mathrm{mg}$ Cadmium on the chemical forms of Cadmium in Clay soil in three Incubation times at FC condition.

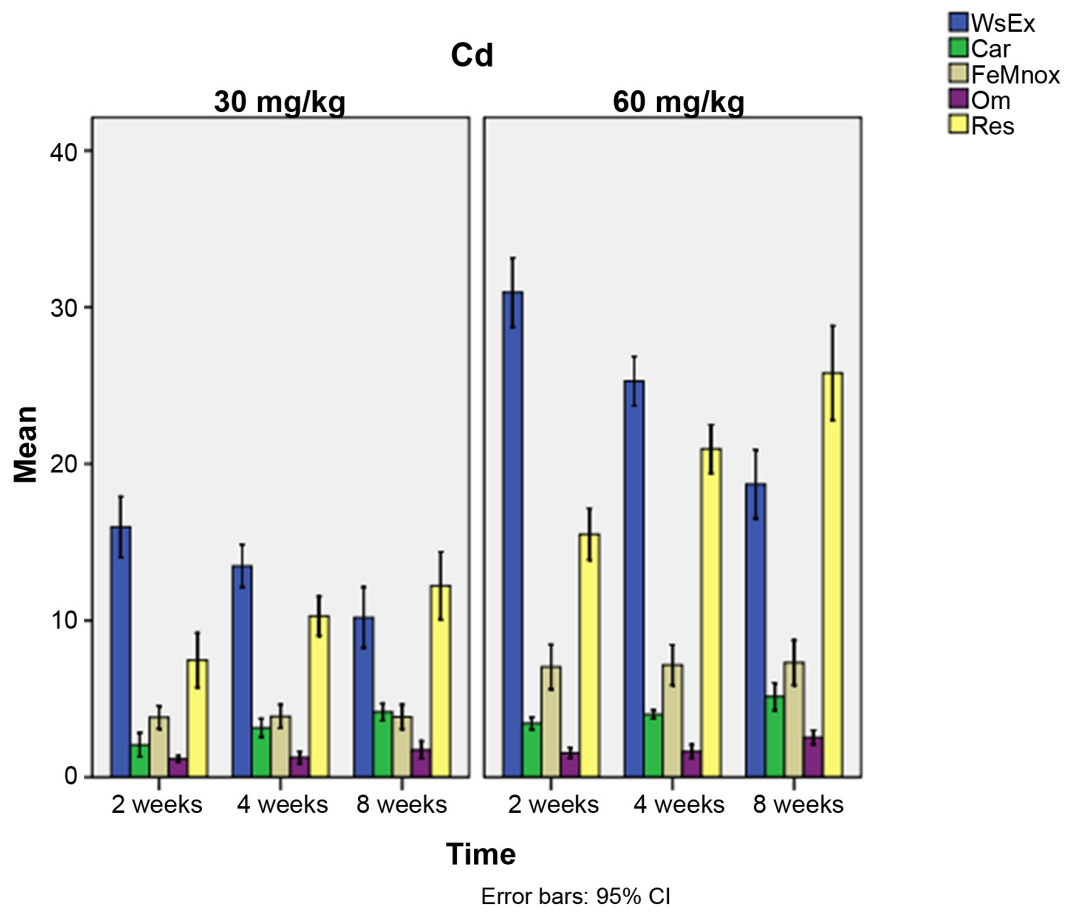

Figure 2. Effect of 30 and $60 \mathrm{mg}$ Cadmium on the chemical forms of Cadmium in sandy clay loam soil in three Incubation times at FC condition.

soluble-exchangeable form decreased significantly from 15.57 and 16.15 to 8.64 and $9.39 \mathrm{ppm}$ for clay and sandy clay loam respectively and the concentration of 
cadmium in carbonate, organic matter and residual forms increased after 8 weeks of incubation time. The iron and manganese oxides form in both soils did not differ significantly. The correlation coefficients between chemical forms of cadmium and time with Pearson test showed that the carbonate, water soluble-exchangeable and residual forms had the highest correlation coefficient with incubation time in both soils, respectively. Coefficients of correlation between chemical forms of cadmium and incubation time in clay soil were higher than sandy clay loam soil (Table 3 and Table 4). Such data were not unexpected, as the deformations of the soluble metals through time and their conversion into less solubility forms were also reported by other researchers [26] [27] [28]. Lim et al. 2002 [29] observed that although increasing the shaking time from 1 to 7 , $15,30,50$ and 65 days did not have a significant effect on the adsorption of lead and cadmium, but it converted high-solubility metal forms into less soluble forms. However, there was no compelling reason to change the concentration of other forms, but it may be possible to attribute changes of other forms to the dynamics of organic compounds of the soil. In other words, the formation and decomposition of organic matter complexes with metal can be effective in combining or releasing metals in the soil and, in turn, affect the relative amount of other forms. This is clear in soils treated with organic wastes. The effect of incubation time on cadmium chemical forms was different. The passing of time reduced the water soluble-exchangeable form in both soils. Lu et al. 2005 [30] added $500 \mathrm{mg} / \mathrm{kg}$ of copper, zinc and lead and $2.5 \mathrm{mg} / \mathrm{kg}$ of cadmium to three areas of tropical regions of China, and examined the chemical forms of these metals during 8-week incubation period. The results showed that, three hours after incubation the main part of metals was in the exchangeable form. Cadmium was slowly converted to other forms while other metals quickly turned into other chemical forms. After adding cadmium to the soils, a significant amount

Table 3. Correlation coefficients between chemical forms of cadmium (mg/kg soil) and incubation time in clay soil at FC condition.

\begin{tabular}{ccccccc}
\hline & Time & WsEx & Car & FeMnox & Om & Res \\
\hline Pearson Correlation & 1 & $-0.628^{* *}$ & $0.803^{* *}$ & 0.000 & $0.684^{* *}$ & $0.634^{\star *}$ \\
Sig. (2-tailed) & & 0.000 & 0.000 & 1.000 & 0.000 & 0.000 \\
$\mathrm{~N}$ & 36 & 36 & 36 & 36 & 36 & 36 \\
\hline
\end{tabular}

${ }^{* *}$ Is significant at 0.01 level.

Table 4. Correlation coefficients between chemical forms of cadmium (mg/kg soil) and incubation time in sandy clay loam soil at FC condition.

\begin{tabular}{cccccccc}
\hline & & Time & WsEx & Car & FeMnox & Om & Res \\
\hline \multirow{2}{*}{ Time } & Pearson Correlation & 1 & $-0.373^{*}$ & $0.744^{\star *}$ & 0.000 & $0.602^{\star *}$ & $0.417^{\star}$ \\
& Sig. (2-tailed) & & 0.025 & 0.000 & 1.000 & 0.000 & 0.011 \\
& $\mathrm{~N}$ & 36 & 36 & 36 & 36 & 36 & 36 \\
\hline
\end{tabular}

** and ${ }^{*}$ are significant at 0.01 and 0.05 level respectively. 
of Cadmium was entered into the water soluble-exchangeable form and then, gradually separated from this form and entered into other forms. As much as 50\% of added cadmium to the soils was extracted in a water soluble-exchangeable form after 2 weeks. With increasing duration time, cadmium concentration in this form was reduced and entered into carbonate and organic and residual forms (Table 3 and Table 4).

\subsection{Effect of Incubation Time on Chemical Forms of Cadmium at Waterlogged Regime}

Statistical data showed, flooding condition decreased the concentration of cadmium in water soluble + exchangeable form and increased the concentration of cadmium in the forms of Fe-Mn oxides, carbonate and organic matter (Figure 3 and Figure 4). As it can be seen, the iron and manganese oxides form in clay soil is significantly different over the time, but there is no significant difference in sandy clay loam soil. The correlation coefficients between chemical forms of cadmium and incubation time with Pearson test showed that the carbonate, water soluble-exchangeable, residual, organic matter and iron and manganese oxides forms had the highest correlation coefficient with incubation time in clay soils, respectively. In sandy clay loam soil the carbonate, organic matter, water soluble-exchangeable and residual forms had the highest correlation coefficients with incubation time, respectively. The iron and manganese oxides form did not show significant correlation with incubation time in sandy clay loam soil (Table 5 and Table 6). Results from our study show that $\mathrm{Cd}$ is associated with carbonates, ferrihydrite, humic acid, and CdS during flooding period. Number of Cd

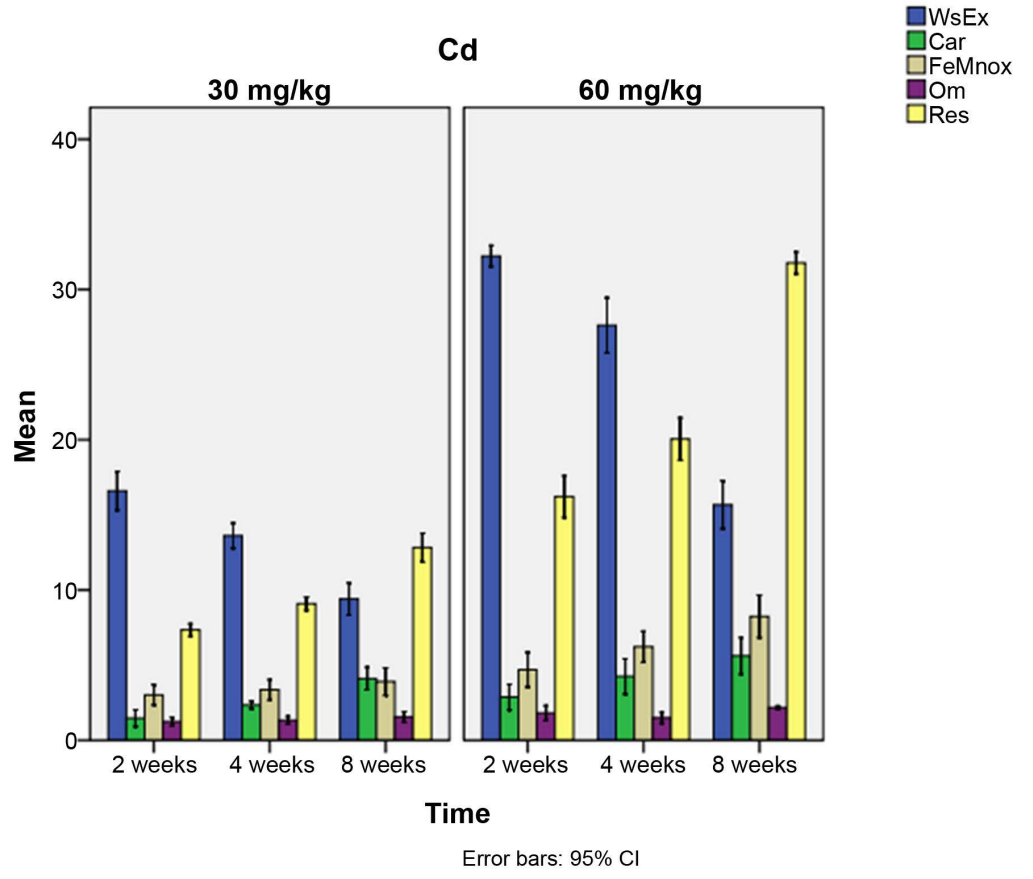

Figure 3. Effect of 30 and $60 \mathrm{mg}$ Cadmium on the chemical forms of Cadmium in Clay soil in three Incubation times at waterlogged condition. 


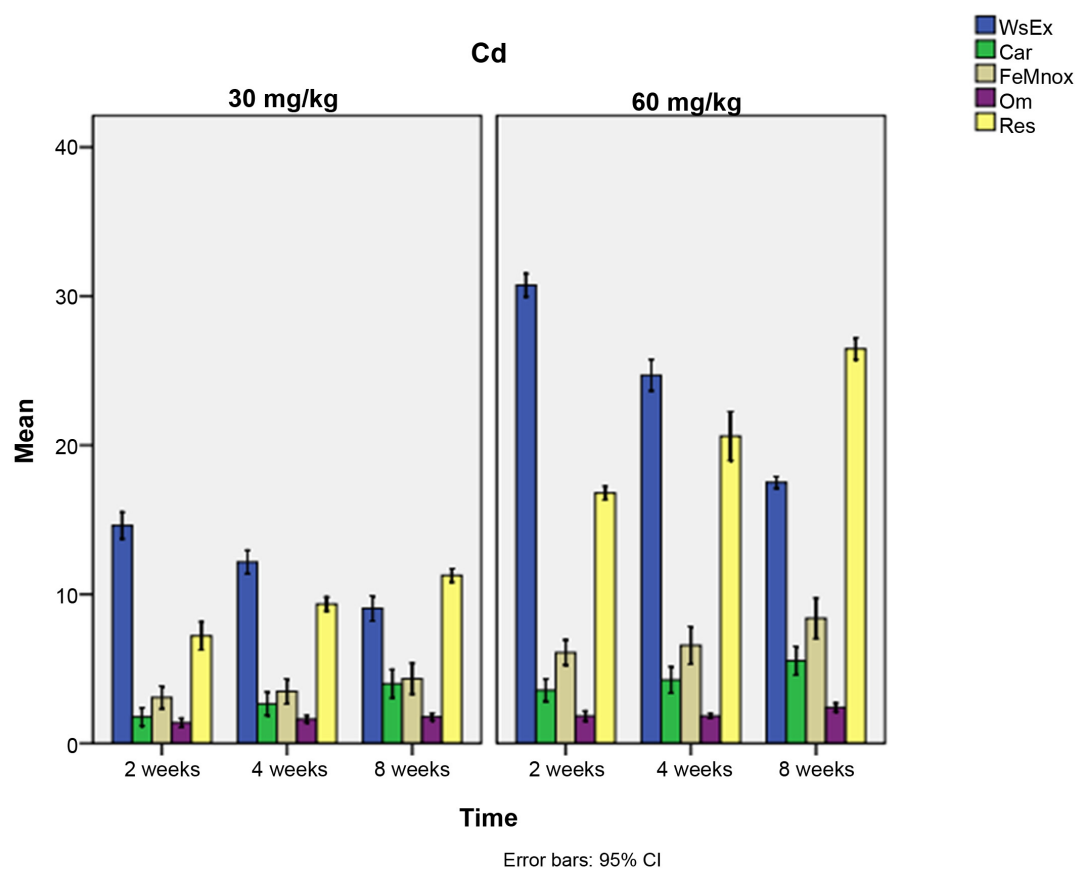

Figure 4. Effect of 30 and $60 \mathrm{mg}$ Cadmium on the chemical forms of Cadmium in sandy clay loam soil in three Incubation times at waterlogged condition.

Table 5. Correlation coefficients between chemical forms of cadmium (mg/kg soil) and incubation time in clay soil at waterlogged condition.

\begin{tabular}{cccccccc}
\hline & & Time & WsEx & Car & FeMnox & Om & Res \\
\hline \multirow{2}{*}{ Time } & Pearson Correlation & 1 & $-0.598^{* *}$ & $0.810^{* *}$ & $0.357^{*}$ & $0.362^{\star}$ & $0.525^{\star *}$ \\
& Sig. (2-tailed) & & 0.000 & 0.000 & 0.033 & 0.030 & 0.001 \\
& $\mathrm{~N}$ & 36 & 36 & 36 & 36 & 36 & 36 \\
\hline
\end{tabular}

** and ${ }^{*}$ are significant at 0.01 and 0.05 level respectively.

Table 6. Correlation coefficients between chemical forms of cadmium (mg/kg soil) and incubation time in sandy clay loam soil at waterlogged condition.

\begin{tabular}{cccccccc}
\hline & & Time & WsEx & Car & FeMnox & Om & Res \\
\hline \multirow{3}{*}{ Time } & Pearson Correlation & 1 & $-0.536^{* *}$ & $0.774^{* *}$ & 0.157 & $0.582^{* *}$ & $0.360^{*}$ \\
& Sig. (2-tailed) & & 0.001 & 0.000 & 0.361 & 0.000 & 0.031 \\
& $\mathrm{~N}$ & 36 & 36 & 36 & 36 & 36 & 36 \\
\hline
\end{tabular}

** and * are significant at 0.01 and 0.05 level respectively.

complexes with humic acids released into soil solution during flooding condition due to slight decrease in $\mathrm{pH}$ and remarkable increase in Eh. Carbonate minerals and organic matters adsorb the amount of $\mathrm{Cd}$ released from humic substances. These findings are supported by results from studies by Jung and Thornton 1997 [31] that showed under anaerobic conditions (flooding), Cd largely bound to Fe-Mn (hydr) oxides. Flooding leads to decreasing exchangeable $\mathrm{Cd}$ while increasing the concentration of $\mathrm{Cd}$ in $\mathrm{Fe}-\mathrm{Mn}$ (hydr) oxides and or- 
ganic matter forms. Evolution of reducing condition in soil causes a decrease Cd solubility over the formation of CdS complexes [3] [4]. Guo et al. 1997 [32] showed that with decreasing $\mathrm{Eh}$ in 60 days suspension experiments, $\mathrm{Cd}$ bound to carbonate, humic substances and sulfide increased while $\mathrm{Cd}$ bound to $\mathrm{Fe}-\mathrm{Mn}$ (hydr) oxides form decreased.

\subsection{Effect of Different Levels of Cadmium on the Chemical Forms of Cadmium}

In both soils, and at all times, with increasing cadmium levels, all the chemical forms of cadmium increased significantly. Increasing in all chemical forms of cadmium, at the beginning of the experiment indicates a rapid achievement of the balance and precipitation of cadmium in the form of mineral phases. This shows the high capacity of the soils to absorb and maintain cadmium. However, in soils with light texture, the presence of metals such as cadmium in the more usable forms has been reported by other researchers [33] [34] [35] but the effect of cadmium levels on the chemical forms of this element has been considered less. In the present experimental conditions, the effect of cadmium levels on the distribution of the chemical forms of Cadmium can be attributed to the different capacities of soil components for the storage of cadmium. In other words, due to the limited capacity of some soil components to maintain cadmium, by increasing the level of this element, cadmium enters the components that have more capacity to maintain the element. As can be seen, the correlation between cadmium levels and water soluble-exchangeable, iron and manganese oxides and organic matter forms in clay soil are higher than sandy clay loam and in sandy clay loam the residual form is higher than clay soil at field capacity regime (Table 7 and Table 8). Correlation between cadmium levels and all cadmium chemical forms in sandy clay loam are higher than clay soil at waterlogged regime (Table 9 and Table 10).

Table 7. Correlation coefficients between chemical forms of cadmium (mg/kg soil) and cadmium levels in clay soil at FC condition.

\begin{tabular}{cccccccc}
\hline & & Cd & WsEx & Car & FeMnox & Om & Res \\
\hline & Pearson Correlation & 1 & $0.788^{\star *}$ & $0.508^{\star *}$ & $0.888^{\star *}$ & $0.487^{\star *}$ & $0.637^{\star *}$ \\
$\mathrm{Cd}$ & Sig. (2-tailed) & & 0.000 & 0.002 & 0.000 & 0.003 & 0.000 \\
& $\mathrm{~N}$ & 36 & 36 & 36 & 36 & 36 & 36 \\
\hline
\end{tabular}

**Is significant at 0.01 level.

Table 8. Correlation coefficients between chemical forms of cadmium (mg/kg soil) and cadmium levels in sandy clay loam soil at FC condition.

\begin{tabular}{cccccccc}
\hline & & Cd & WsEx & Car & FeMnox & Om & Res \\
\hline & Pearson Correlation & 1 & $0.753^{* *}$ & $0.508^{* *}$ & $0.858^{* *}$ & $0.411^{* *}$ & $0.641^{* *}$ \\
$\mathrm{Cd}$ & Sig. (2-tailed) & & 0.000 & 0.002 & 0.000 & 0.004 & 0.000 \\
& $\mathrm{~N}$ & 36 & 36 & 36 & 36 & 36 & 36
\end{tabular}

**Is significant at 0.01 level. 
Table 9. Correlation coefficients between chemical forms of cadmium (mg/kg soil) and cadmium levels in clay soil at waterlogged condition.

\begin{tabular}{cccccccc}
\hline & & Cd & WsEx & Car & FeMnox & Om & Res \\
\hline & Pearson Correlation & 1 & $0.738^{* *}$ & $0.500^{* *}$ & $0.811^{* *}$ & $0.486^{* *}$ & $0.790^{* *}$ \\
Cd & Sig. (2-tailed) & & 0.000 & 0.002 & 0.000 & 0.003 & 0.000 \\
& $\mathrm{~N}$ & 36 & 36 & 36 & 36 & 36 & 36 \\
\hline
\end{tabular}

${ }^{* *}$ Is significant at 0.01 level.

Table 10. Correlation coefficients between chemical forms of cadmium (mg/kg soil) and cadmium levels in sandy clay loam soil at waterlogged condition.

\begin{tabular}{cccccccc}
\hline & & Cd & WsEx & Car & FeMnox & Om & Res \\
\hline & Pearson Correlation & 1 & $0.793^{* *}$ & $0.538^{* *}$ & $0.821^{* *}$ & $0.542^{* *}$ & $0.880^{* *}$ \\
Cd & Sig. (2-tailed) & & 0.000 & 0.001 & 0.000 & 0.001 & 0.000 \\
$\mathrm{~N}$ & 36 & 36 & 36 & 36 & 36 & 36 \\
\hline
\end{tabular}

${ }^{* *}$ Is significant at 0.01 level.

\subsection{Effect of Soil Texture on Cadmium Chemical Forms}

The average of the data showed that the concentration of cadmium in residual form was higher in clay soil. In sandy clay loam soil, water soluble-exchangeable, carbonate and organic matter forms were higher than clay soil. The Iron-manganese oxides form showed no significant difference in two soils at field capacity regime (Table 11). In flooding conditions, the concentration of the water soluble-exchangeable form decreased and the concentration of other forms increased. In contrast to the oxidizing conditions, at the reduction conditions no significant difference was observed in the residual and organic matter forms in two soils (Table 12). Also, the results showed that in all treatment for clay soil

Table 11. Impact of soil texture on chemical forms of cadmium at FC condition.

\begin{tabular}{cccccc}
\hline \multicolumn{5}{c}{ Cadmium Chemical Forms mg/Kg } \\
\hline Soil & WsEx & Car & Fe-MnOx & Om & Res \\
\hline Sandy clay loam & $20 / 32 \mathrm{a}$ & $3 / 48 \mathrm{a}$ & $5 / 29 \mathrm{a}$ & $1 / 75 \mathrm{a}$ & $13 / 18 \mathrm{~b}$ \\
Clay & $18 / 14 \mathrm{~b}$ & $3 / 14 \mathrm{~b}$ & $5 / 15 \mathrm{a}$ & $1 / 46 \mathrm{~b}$ & $15 / 96 \mathrm{a}$ \\
\hline
\end{tabular}

The numbers in each column have a common alphabet do not differ significantly from the Duncan test at $5 \%$ level.

Table 12. Impact of soil texture on chemical forms of cadmium at waterlogged condition.

\begin{tabular}{cccccc}
\hline \multicolumn{5}{c}{ Cadmium Chemical Forms mg/Kg } \\
\hline Soil & WsEx & Car & Fe-MnOx & Om & Res \\
\hline Sandy clay loam & $18 / 89 \mathrm{a}$ & $3 / 99 \mathrm{a}$ & $5 / 72 \mathrm{a}$ & $1 / 98 \mathrm{a}$ & $15 / 10 \mathrm{a}$ \\
Clay & $17 / 34 \mathrm{~b}$ & $3 / 56 \mathrm{~b}$ & $5 / 65 \mathrm{a}$ & $1 / 82 \mathrm{a}$ & $16 / 26 \mathrm{a}$ \\
\hline
\end{tabular}

The numbers in each column have a common alphabet do not differ significantly from the Duncan test at $5 \%$ level. 
and sandy clay loam, $68.98 \%$ and $70.89 \%$ of added cadmium to soils were extracted by three first extractants. With a little attention to these data, it becomes clear that in both soils, a major portion of cadmium was associated with water soluble-exchangeable, Iron-manganese oxides and carbonates forms, which indicate of high bioavailability of cadmium in the soils. Because these forms compared to others are extracted with a weaker extractor $s$ which are not very acidic. Through the mentioned forms, the water soluble-exchangeable was the dominant form. Almost all cadmium was removed by three first relatively weak extractors. The higher concentration of Cadmium in water soluble-exchangeable and carbonate forms in the sandy clay loam also reflects the greater bioavailability of cadmium in light texture soils, which has been reported by other researchers [35] [36] [37].

\section{Conclusion}

After adding cadmium to the soils, a significant amount of this metal was entered into water soluble-exchangeable form and gradually separated from this form and entered into other forms. As much as $50 \%$ of the added cadmium was extracted in the water soluble-exchangeable form after two weeks. With increasing time, the cadmium concentration in this form was reduced and cadmium was entered into carbonate, organic and residual forms. In both textures and at all times, with increasing cadmium levels, all the chemical forms of cadmium increased significantly. The increase of all chemical forms of cadmium at the beginning of the experiment indicates a rapid achievement of the equilibrium and precipitation of cadmium in the form of mineral phases, which shows the high capacity of the soils to absorb and maintain cadmium. Flooding condition decreased the concentration of cadmium in water soluble + exchangeable form and increased the concentration of cadmium in the forms of Fe-Mn oxides, carbonate and organic matter. Concentration of cadmium in residual form was higher in clay soil. In sandy clay loam soil, water soluble-exchangeable, carbonate and organic matter forms were higher than clay soil. The iron-manganese oxides form showed no significant difference in two soils at field capacity regime. In flooding conditions, the concentration of the water soluble-exchangeable form decreased and the concentration of other forms increased. In contrast to the oxidizing conditions at the reduction conditions, no significant difference was observed in the residual and organic matter forms in two soils.

\section{Acknowledgements}

The authors appreciate the Islamic Azad University of Isfahan, Khorasgan Branch, Soil Science Department.

\section{Conflicts of Interest}

The authors declare no conflicts of interest regarding the publication of this paper. 


\section{References}

[1] Adriano, D.C. (1986) Trace Elements in the Terrestrial Environment. Springer, New York. https://doi.org/10.1007/978-1-4757-1907-9

[2] Kashem, M.A. and Singh, B.R. (2001) Metal Availability in Contaminated Soils: I. Effects of Flooding and Organic Matter on Changes in Eh, $\mathrm{pH}$ and Solubility of Cd, $\mathrm{Ni}$ and Zn. Nutrient Cycling in Agroecosystems, 61, 247-255. https://doi.org/10.1023/A:1013762204510

[3] Zheng, S., Zheng, X. and Chen, C. (2013) Transformation of Metal Speciation in Purple Soil as Affected by Water Logging. International Journal of Environmental Science and Technology, 10, 351-358. https://doi.org/10.1007/s13762-012-0146-3

[4] De Livera, J., McLaughlin, M.J., Hettiarachchi, G.M., Kirby, J.K. and Beak, D.G. (2011) Cadmium Solubility in Paddy Soils: Effects of Soil Oxidation, Metal Sulfides and Competitive Ions. Science of the Total Environment, 409, 1489-1497. https://doi.org/10.1016/j.scitotenv.2010.12.028

[5] Loganathan, P., Vigneswaran, S., Kandasamy, J. and Naidu, R. (2012) Cadmium Sorption and Desorption in Soils: A Review. Critical Reviews in Environmental Science and Technology, 42, 489-533. https://doi.org/10.1080/10643389.2010.520234

[6] Hindersmann, I. and Mansfeldt, T. (2014) Trace Element Solubility in a Multimetal-Contaminated Soil as Affected by Redox Conditions. Water, Air, \& Soil Pollution, 225, 1-20. https://doi.org/10.1007/s11270-014-2158-8

[7] Gray, C.W., McLaren, R.G., Roberts, A.H.C. and Condron, L.M. (1999) Solubility, Sorption and Desorption of Native and Added Cadmium in Relation to Properties of Soils in New Zealand. European Journal of Soil Science, 50, 127-137. https://doi.org/10.1046/j.1365-2389.1999.00221.x

[8] McLaren, R.G. and Cameron, K.C. (1996) Soil Science: Sustainable Production and Environmental Protection. 2nd Edition, Oxford University Press, Auckland, New Zealand, 340 .

[9] Agbenin, J.O. and Olojo. L.A. (2004) Competitive Adsorption of Copper and Zinc by a Bt Horizon of a Savanna Alfisol as Affected by $\mathrm{pH}$ and Selective Removal of Hydrous Oxides and Organic Matter. Geoderma, 119, 85-95.

https://doi.org/10.1016/S0016-7061(03)00242-8

[10] Gao, X. (2007) Bioavailability of Zinc to Aerobic Rice. Wageningen University \& Research Centre, Wageningen, Netherlands.

[11] Soil Survey Staff, Natural Resources Conservation Service. Official Soil Series Descriptions. United States Department of Agriculture.

[12] Gee, G.W. and Bauder, J.W. (1986) Particle-Size Analysis. In: Klute, A., Ed., Methods of Soil Analysis, Part 1. Physical and Mineralogical Methods, 2nd Edition, ASA, SSSA, Madison, WI.

[13] Gupta, P.K. (2000) Soil, Plant, Water and Fertilizer Analysis. Agrobios, New Dehli, India.

[14] Richards, L.A. (1969) Diagnosis and Improvement of Saline and Alkali Soils.US Salinity Laboratory Staff. Agricultural Handbook, No. 60, USDA, USA.

[15] Nelson, D.W. and Sommers, L.E. (1982) Total Carbon, Organic Carbon and Organic Matter. In: Page, A.L., et al., Eds., Methods of Soil Analysis, ASA, SSSA, Madison, WI, 539-579. 
[16] Lindsay, W.L. and Norvell, W.A. (1978) Development of a DTPA Soil Test for Zinc, Iron, Manganese and Copper. Soil Science Society of America Journal, 42, 421-428. https://doi.org/10.2136/sssaj1978.03615995004200030009x

[17] Hafeez, B., Khanif, Y. and Saleem, M. (2013) Role of Zinc in Plant Nutrition-A Review. American Journal of Experimental Agriculture, 3, 374-391. https://doi.org/10.9734/AJEA/2013/2746

[18] Robert, D.R., Ford, R.G. and Sparks, D.L. (2003) Kinetics and Mechanisms of Zn Complexation on Metal Oxides Using EXAFS Spectroscopy. Journal of Colloid and Interface Science, 263, 364-376. https://doi.org/10.1016/S0021-9797(03)00281-9

[19] Ponnamperuma, F.N. (1972) The Chemistry of Submerged Soils. In: Brady, N.C., Ed., Advances in Agronomy, Vol. 24, Academic Press, Inc., New York and London, 29-96.

[20] Sahrawat, K.L. (2012) Soil Fertility in Flooded and Non-Flooded Irrigated Rice Systems. Archives of Agronomy and Soil Science, 58, 423-436. https://doi.org/10.1080/03650340.2010.522993

[21] Gao, X., Zou, C., Fan, X., Zhang, F. and Hoffland, E. (2006) From Flooded to Aerobic Conditions in Rice Cultivation: Consequences for Zinc Uptake. Plant and Soil, 280, 41-47. https://doi.org/10.1007/s11104-004-7652-0

[22] Yoshida, S. and Tanaka, A. (1969) Zinc Deficiency of the Rice Plant in Calcareous Soils. Soil Science and Plant Nutrition, 15, 75-80.

https://doi.org/10.1080/00380768.1969.10432783

[23] Yu, K.W., Bohme, F., Rinklebe, J., Neue, H.U. and DeLaune, R.D. (2007) Major Biogeochemical Processes in Soils-A Microcosm Incubation from Reducing to Oxidizing Conditions. Science Society of America Journal, 71, 1406-1417. https://doi.org/10.2136/sssaj2006.0155

[24] Kögel-Knabner, I., Amelung, W., Cao, Z.H., Fiedler, S., Frenzel, P., Jahn, R., Kalbitz, K., Kolbl, A. and Schloter, M. (2010) Biogeochemistry of Paddy Soils. Geoderma, 157, 1-14. https://doi.org/10.1016/j.geoderma.2010.03.009

[25] Tessier, A., Campbell, P.G.C. and Bisson, M. (1979) Sequential Extraction Procedure for the Speciation of Particular Trace Elements. Analytical Chemistry, 51, 844-851. https://doi.org/10.1021/ac50043a017

[26] Bell, P.F., James, B.R. and Chaney, R.L. (1991) Heavy Metals Extractability in Long-Term Sewage Sludge and Metal Salt Amended Soils. Journal of Environmental Quality, 20, 481-486. https://doi.org/10.2134/jeq1991.00472425002000020023x

[27] Gleyzes, C., Tellier, S. and Astruc, M. (2002) Fractionation Studies of Trace Elements in Contaminated Soils and Sediments: A Review of Sequential Extraction Procedures. TrAC Trends in Analytical Chemistry, 21, 451-467. https://doi.org/10.1016/S0165-9936(02)00603-9

[28] Hooda, P.S. and Alloway, B.J. (1993) Effects of Time and Temperature on the Bioavailability of $\mathrm{Cd}$ and $\mathrm{Pb}$ from Sludge-Amended Soils. Journal of Soil Science, 44, 97-110. https://doi.org/10.1111/j.1365-2389.1993.tb00437.x

[29] Lim, T.T., Tay, J.H. and Teh, C.I. (2002) Contamination Time Effect on Lead and Cadmium Fractionation in Tropical Coastal Clay. Journal of Environmental Quality, 31, 806-812. https://doi.org/10.2134/jeq2002.8060

[30] Lu, A., Zhang, S. and Shan, X. (2005) Time Effect on the Fractionation of Heavy Metals. Geoderma, 125, 225-234. https://doi.org/10.1016/j.geoderma.2004.08.002

[31] Jung, M.C. and Thornton, I. (1997) Environmental Contamination and Seasonal Variation of Metals in Soils, Plants and Waters in the Paddy Fields around a Pb- $\mathrm{Zn}$ 
Mine in Korea. Science of the Total Environment, 198, 105-121. https://doi.org/10.1016/S0048-9697(97)05434-X

[32] Guo, T., DeLaune, R.D. and Patrick Jr., W.H. (1997) The Influence of Sediment Redox Chemistry on Chemically Active Forms of Arsenic, Cadmium, Chromium, and Zinc in Estuarine Sediment. Environment International, 23, 305-316. https://doi.org/10.1016/S0160-4120(97)00033-0

[33] Gupta, V.K., Gupta, A.P. and Raj, H. (1983) Micronutrient Contents and Yield of Lentil and Maize as Influenced by Direct and Residual Application of Organic Manure and Zinc. Indian Journal of Agricultural Science, 53, 826-830.

[34] Mckenna, I.M., Chaney, R.L. and Williams, F.M. (1993) The Effects of Cadmium and Zinc Interactions on the Accumulation and Tissue Distribution of Zinc and Cadmium in Lettuce and Spinach. Environmental Pollution, 79, 113-120.

https://doi.org/10.1016/0269-7491(93)90060-2

[35] Misra, A.K., Sarkunan, V., Das, M. and Nayar, P.K. (1990) Transformation of Added Heavy Metals in Soils under Flooded Condition. Journal of the Indian Society of Soil Science, 38, 416-418.

[36] Antoniadis, N. and Alloway, B.J. (2001) Availability of Cd, Ni and Zn to Rye Grass in Sewage Sludge Treated Soils at Different Temperatures. Water, Air, and Soil Pollution, 132, 201-204. https://doi.org/10.1023/A:1013202104550

[37] Mahler, R.J., Bingham, F.T., Page, A.L. and Ryan, J.A. (1982) Cadmium-Enriched Sewage Sludge Application to Acid and Calcareous Soils. Journal of Environmental Quality, 11, 694-700. https://doi.org/10.2134/jeq1982.00472425001100040028x 